\title{
The role of Palestinian universities in the Gaza governorates in achieving the social peace for its students and ways to strengthen it: Islamic University as a case study
}

\author{
Fayez Kamal Sheldan and Manal Noman Qwaider
}

Islamic University of Gaza, Palestine.

Accepted 23 November, 2018

\begin{abstract}
The study aimed to identify the role of the Islamic University in Gaza governorate in achieving social peace for its students and ways of enhancing it. The researchers used the descriptive approach, the analytical method. The study population consisted of all 15792 students. The sample of the study was 392 students. A questionnaire of 25 items was administered to the sample members. Data was analyzed using the Statistical Analysis Program (SPSS). The results of the study showed that the role of the Islamic University in the Gaza Governorate in achieving social peace for its students was moderate with a percentile of $67.40 \%$. There were no statistically significant differences of the sample responses to the role of the Islamic University in the governorate of Gaza in achieving social peace for its students due to the variable college, and the variable sex. There were differences of statistical significance attributed to the variable of the level of study in favor of the second level. On the light of the results, the researchers proposed a set of ways to enhance the role of the Islamic University in achieving social peace for its students, such as, Providing students with social responsibility, knowledge of citizenship rights and participation in decisionmaking, the need to train students on the principle of initiative, and the practice of integrated scientific thinking to solve serious problems facing society.
\end{abstract}

Keywords: Social security, Palestinian universities, students, Gaza governorate.

*Corresponding author. E-mail: fshaladan@iugaza.edu.ps.

\section{INTRODUCTION}

Societies regardless of all their political, religious and social conditions seek to achieve peace, security and stability for their members. This is an essential goal for the advancement and progress of civilization, which is the same goal sought by the first primitive man. The Holy Quran referred to peace in more than one place, including saying: But if they incline towards peace, then incline towards it, and put your trust in God. He is the Hearer, the Knower (Anfal: 61).

And those are of the most important criteria for evaluating any society is to diagnose the state of its internal relations. Its safety is a sign of the health of the society and the possibility of its advancement, while its abandonment is a sign of malaise and backwardness, and the instability of society (Hudhud, 2017:6).

The university plays an important role in the society, in general, and in the life of its students in particular. It has responsibility for education and the formation of ideas and believes to its students. It also helps students to understand the reality surrounding them and to quickly integrate and interact with each other. Colleagues, and integration with the spirit of the community, whose values are positive ideas about the other, thus promoting a culture of social peace among them. 
In the opinion of the researchers, the issue of achieving social peace is a matter of concern to all of us, as citizens who seek to live in a homeland full of security and stability. Social peace is very important to any society. If society is not stable, prosperous and secure, it cannot be strong and prosperous. The achievement of social peace and stability was a concern for the lives of nations and societies and for the youth in particular.

If the situation of social peace is lost or weakened, the natural consequence of this is the deterioration of security and instability, where there is a state of conflict and strife, and each party seeks to inflict the greatest harm and harm on the other side, and then lose borders, violate freedoms and destroy interests (Alsafar, 2002).

A culture of social peace means that a culture of dialogue, discussion and persuasion prevails in our dealings with others, rather than imposing one opinion by force or threat, and resolving the problems that may arise through negotiation rather than through violence (Balmouchi, 2014:322).

The researchers believe that universities play an important role in establishing the rules of social peace between their students. They teach the values of justice and peace, raise them to the desired level, and have sufficient influence in modifying the behavior of students inside and outside the university; and, the integration of all aspects of the personality of the student, so it must play its role as an educational median and contribute to the promotion and dissemination of this culture.

The despair and frustration of some university youths and the loss of confidence in the future, in addition to many other factors such as poverty, high rates of unemployment, the spread of civil wars, acute class inequalities, lack of social justice and the supremacy of the principle of force above the law, between the social structures, pose a threat to social peace. When young people feel that they have no place in their home countries, and that all doors are closed, what do we expect from those young people who have no vision or goal? and see life as contradicted views. This feeling of frustration in addition to misconception of religion leads to violence, and revenge against a painful reality.

Despite the importance of the subject of social peace and the extent of its achievement among university students, there is a scarcity of research and studies that dealt with this field from the educational point of view. The results of the Jekkoub (2017) study proved that there is a correlation between the economic crisis and the loss of social peace. The results of the study of Al-Assali and Swaydan (2012) revealed that the analysis of the content of the curriculum dealt with the concept and dimensions of social peace and the role of good citizenship in its construction, but in a random and unorganized way that focused on some indicators and neglected others, and did not achieve horizontal integration between the various subjects adequately, thus affecting the final outputs in terms of student personality and its impact on society.

\section{Study problem and questions}

The loss of social peace is a general phenomenon witnessed by different societies. As university youth are characterized by diversity and verity, with different interests and attitudes, and a diverse view of the present and the future, how can social peace be achieved among them? It is clear to everyone that the Palestinian society is undergoing rapid changes in all aspects of economic, social and cultural life, which have affected the cohesion and stability of the society and the emergence of vague attitudes, values and patterns of thinking adopted by the university youth, which are not consistent with the nature of the conservative Palestinian society. During the course of their work in the Palestinian universities, the researchers realized the need to conduct this study to learn about the role of the Islamic University in achieving social peace among its students, and the extent of developing this role to promote the concepts of social peace represented in security and stability and interrelated relations and tolerance.

\section{Study questions}

1. What is the role of the Islamic University in the governorates of Gaza in achieving social peace among its students from their point of view?

2. Are there statistically significant differences at the level of significance $(\alpha \leq 0.05)$ among the average of the sample of the study sample about the role of the Islamic University in the Gaza governorates in achieving social peace among their students due to the variables (gender, college, level of study)?

3. What are the proposed ways to enhance the role of the Islamic University in the Gaza governorates in achieving social peace among its students?

\section{Objectives}

The study aims to:

1. Recognize the role of the Islamic University in the governorates of Gaza in achieving social peace among its students from their point of view.

2. Detect the existence of statistically significant differences at the level of significance $(\alpha \leq 0.05)$ among the average of the sample of the study sample about the role of the Islamic University in the Gaza governorates in achieving social peace among their students due to the variables (gender, college, level of study).

3. Reach some means to enhance the role of the Islamic University in Gaza Governorate in achieving social peace among its students, which is compatible with the economic, social and political situation of the Palestinian society. 
4. To enhance the concept of social peace and its importance in stability of society and the fulfillment of its goals.

\section{Importance of the study}

1. The importance of the topic stems from the importance of the role of the University in refining the personality of university youth and providing it with the necessary expertise in achieving social peace. The university is no longer an academic institution that grants diplomas, but is a community institution that responds to its students' needs in a renewed manner.

2. Proposing a range of possible ways to enhance the role of the Islamic University in achieving social peace in a greater and deeper manner.

3. Their importance stems from the scarcity of similar studies in the Palestinian environment, according to researchers' knowledge.

4. The results of this study may benefit the following:

- Administrators of the Palestinian Universities.

- Academic staff.

- Graduate Students and researchers to open new horizons in the field of social peace.

\section{Limits of the study}

- Subject Limit: The study was limited to identifying the role of the Islamic University in the Gaza governorates in achieving social peace among its students specified in the following fields (university administration - faculty members - curriculum).

- Population Limit: A representative sample of students of the Islamic University.

- Institutional Limit: Islamic University.

- Geographical Limit: Gaza Governorates, Palestine.

- Time Limit: The study was implemented in the second semester 2017-2018.

\section{Terminology of study}

- Peace: a word that expresses an innate inclination in the depths of every human being and a unbridled desire among every community, and constitutes a noble goal for all nations and peoples. Peace is innocence and wellness and survival from defects, pests and dangers (Al-Saffar, 2002:30).

- Social peace: It is the situation that brings together a group of people who are different from each other, whether in their religious affiliation or social or functional position, and all of them are united in an unwritten commitment between them, dealing with the rights and duties of each party in society in peace, love and
Harmony (Abu Jidian and Taha, 2012:5).

- The researchers define the role of the Islamic University in achieving social peace operationally as: the actual degree obtained through the estimates of the sample on the study tool on the role of Palestinian universities in the Gaza Strip in achieving social peace among the student, which was prepared for this purpose.

\section{Theoretical framework}

Educational institutions play a major role in creating the right ground for peace between their students. The first nucleus for social peace is the dissemination of a culture of tolerance and the rejection of intolerance and violence, where young people represent a large part of the formation of their societies and have a great responsibility for social interaction, with the limited potential of their communities.

\section{Concept of peace}

The concept of peace language: The peace of peace and its origin Safety, safety and peace: Originally the innocence of the defect and pests, and the peace of the names of Allah for his safety of imperfection, defect and annihilation (Hussaini, 2000:371).

Peace, in terms of terminology, means the absence of war in human societies, the absence of everything related to violence, such as crimes and terrorism. It also means achieving harmony, harmony and peace. Peace does not only mean the absence of violence, but also the desired qualities in every society; to the agreement and the desire to achieve harmony and calm in the relations between individuals and groups (Kilani and Tafha, 2012:25).

The concept of peace is mentioned in the Holy Quran, and it is repeated in more than fifty places. The Almighty said: "Allah calls upon Dar es Salaam and guides whoever he wishes to a straight path." [Yunus: 25] And he also said: "Do not say to those who have given you peace you are not a believer [An-Nisaa: 94].

As for social peace: Al-Badiywi (2011) defined it as a state of peace, harmony, stability, security and a comprehensive justice for the rights of individuals within society, between its classes and forces, or between communities (Badawi, 2011:12).

There are three concepts used in relation to the concept of peace as mentioned by Omar (2016:236), which are as follows:

1. Making peace: helping the parties of the conflict to reach a negotiated agreement.

2. Peace-building: creating the conditions of society so that society can live in peace.

3. Keeping order: It is to prevent the parties of the conflict 
from fighting with each other.

Social peace: is synonymous with civil peace, which means that a person must live his life and exercise his duties freely and responsibly, and obtain the requirements of his life and rights easily and without fearing for his rights, money, personal security, or the security of his family (Amer et al., 2013:7).

The concept of social peace also refers to the rejection of incitement, or justification of all forms of fighting or conflict through the publication of articles, speeches or conferences that incite insecurity and social peace.

The concept of social peace requires a fundamental analysis of two aspects: social peace on the one hand, and the means to achieve it on the other, where the state of social peace can be characterized by the right to decent life, and rights to education, housing and work, to protect the achievement of a decent life for man (Omar, 2016:238).

\section{Philosophy of social peace}

The Quranic philosophy of social peace is based on rules to protect man in his transactions, life, property and reputation, and to liberate him from all that he devotes to thought and conscience. The Prophet (peace and blessings of Allah be upon him) said: "The Muslim is a brother to another Muslim. He does not wrong him, nor surrenders him (Sahih Muslim, 1987:49), and Islam protects the human from contempt, ridicule, humiliation, rumor and espionage, and addresses the source of prejudices by forbidding misgivings, and forbidding the incitement of hatred in society. All these guarantees and ensure the Islamic factors of social peace, because in no way can We build a safe country without realizing internal security to its people, and spreading social peace among them (Majidi, 2014).

\section{Social peace industry}

The responsibility to build and maintain social peace, and the peace of its people, is the duty of all, and comes at the highest religious and social duties, and requires the community to carry out its duties fully to achieve it, and this is guided by our noble messenger in likening the community to the ship, and Prophet Mohammed (Peace be upon him) said, "The likeness of the man who observes the limits prescribed by Allah and that of the man who transgresses them is like the people who get on board a ship after casting lots. Some of them are in its lower deck and some of them in its upper (deck). Those who are in its lower (deck), when they require water, go to the occupants of the upper deck, and say to them: 'If we make a hole in the bottom of the ship, we shall not harm you.' If they (the occupants of the upper deck) leave them to carry out their design they all will be drowned. But if they do not let them go ahead (with their plan), all of them will remain safe" (Albdeiwi, 2011:17).

\section{Elements of social peace}

The question is not within the limits of desire or in the existence of theoretical conviction, but in relation to the reality of the life of society, and the form of relations governing between its forces and groups, and perhaps one of the most important elements of social peace according to the study of Gebkub (2017), including:

1. Justice and equality: Justice is one of the most dangerous values of society at all, and most importantly, because the integrity of society and its provisions in accordance with the value of justice inevitably leads to the rescue of many other basic social values. Justice refers to equality in the equal application of the provisions and laws, and social peace among the members of society. If human rights are secured by justice, this in turn reflects the deepening of their belonging and loyalty to society.

2. Ensuring the legitimate rights and interests of the various groups of society: The societies are diverse in their ethnic, religious or sectarian affiliations, or the like of all classifications, so that everyone should ensure their legitimate rights and interests under the system and the law through social interaction; the social ladder in society, and closing the doors of strife and conflict (Jqobob, 2017:10).

Saleh (2002) suggested another social peace pillar:

3. Power and order: It is a governing authority and a prevailing system, which bears the management of the affairs of society, so that all forces operate under the roof of prestige, otherwise the alternative will be conflicts and chaos among the different segments of society, where power is an important social phenomena that leave their effects on society, These effects may vary depending on the diversity of powers and the duration of power in society. The effects of the interaction of society with power are important whether these social effects are associated with the existence of power or after its collapse for the continuation of the legitimacy and permanence of power. In order to build its entity and justify its existence, it is an important necessity to organize the march of society, and psychologically carries the meanings of a sense of security and safety, and embodies its moral mission to justice and equality among members of the same society, and including these meanings devote their legitimacy to exercise their power and not to impose it regardless of the quality of its authority (Saleh, 2002:14).

It is clear that the more harmony and cooperation between the different sectors of society, the stronger the social fabric, and the more cohesion among its members; 
and this ultimately leads to the strengthening and construction of the home front of the homeland. In contrast, the more violence and conflict within the community has weakened the network of relations between groups of society and its spectra, which leads to the dismantling of ties and turn it into a society dedicated to underdevelopment.

\section{Education and social peace}

Adam (2013) believes that the concept of social peace is closely related to the policies and directions taken by governments, whether those related to economic, political or cultural management. Therefore, educational reforms aimed at achieving a high degree of peace and social harmony are primarily political, play an essential role in achieving a high degree of social recovery and breaking the cycle of conflict in countries suffering from wars, conflicts and civil strife. In contrast, educational policies can generate more schisms and cracks within the social fabric.

The researchers believe that there are major dimensions that directly affect the students' understanding of the culture of social peace and the appreciation and respect of the rights of others. It is represented in the prevailing democratic environment and the appropriate educational environment that contributes to building the personality of the student. The curriculum is of interest in establishing socially responsible behavior, interacting with the student's abilities, and its behavioral practices that reflect its roots and national belonging.

The protection of social peace from the effects of opposing factors: The issue of social peace in the reality of university youth, and the Palestinian society in general, which is still passing through successive crises, the hotbeds of tension and the horrific events resulting from the occupation, and its repercussions The long occupation of our country has cast a dark shadow on our people. Its effects have caused a deep scarring in the social, intellectual and cultural structure of our societies and our youth in particular. It is no different that the cycle of violence and counter-violence, Which the Palestinian people suffered from the first Nakba to this day, has directly affected the behavior and attitudes of individuals, as there were no civil behaviors that rise to the required level (Awad, 2014:385).

Islam's social perspective: Majidi (2014) points out that Islam considers social peace as an obligatory and obligatory duty on the individual towards his society, and a duty in kind to the state towards its citizens. The scholars also classify social peace as a necessity of "fraternal and humanistic architecture" (Interpretation of the meaning): "O ye who believe! Enter in all the peace, and do not follow the footsteps of the devil, for he is to you a clear enemy." [Al-Baqarah: 208]. The culture of peace is a theoretical culture composed of values, principles and concepts, as well as a behavioral culture composed of attitudes, feelings, attitudes and behaviors (Majidi, 2014).

Previous studies: A number of previous studies have been reviewed in this subject which included the following:

Jibqoub (2017) conducted a study aimed at identifying the problem of social peace in light of the economic crises in the Arab world, how the regime dealt with the various cases of loss of social peace, and presented some perceptions of the future of social peace in Algeria. $\mathrm{He}$ stressed that there is a correlation between the economic crisis and social peace, where the specter of unemployment, low salaries and high poverty rates threatened social peace.

Salah (2015): A study aimed at understanding the role of intellectual security in achieving social peace and promoting the idea of moderation and moderation which is in harmony with the essence of the Islamic religion which rejects extremism and fanaticism, which puts social peace at great risk. And the centrality among the public opinion is an active weapon in the containment of extremist thought as a phenomenon on the scene, in addition to effective communication with the march of human civilization and deepening moral and spiritual value to serve the Renaissance project of the nation represents a mature work and step in the right direction in the agreement.

In his study, Balamoshi (2004) sought to know the role of educational curricula in achieving a culture of social peace. He emphasized that education was based on the social basis by which societies achieved education by nurturing the generation and helping them adapt to desired behavior in society, and educational curricula is considered the link between education as the theoretical framework based on the values of social, cultural, psychological and cognitive, and education as an applied aspect, but those interested in education agree that the curricula in general and curricula of Islamic education in particular do not rise to the desired level in enhancing the called culture of Islam, in accordance to its effect on the generation inside the school or outside.

Adam (2013) studied the role of education in the development and promotion of social peace and how education can be used as a vague mechanism for building social peace. In the profound changes of today's world, governments are unable to impose social peace without resorting to help from many social institutions, especially the educational institution.

Abu-Salama and Salem (2012) by highlighting the citizenship and its impact on the values of belonging and social peace among the students of Al Quds Open University, stressed on the existence of a positive correlation between citizenship and social peace.

Assaf (2012) discussed the relationship between social peace and the mediation of religious discourse. He 
pointed out that the consolidation of social peace in society depended on religious discourse moving away from all forms of exaggeration. And the approach to address these causes is the return of religious discourse to mediate and moderation, and to protect society from neglect and negligence, and thus leading to social peace and protection of society from destruction and destruction.

Asali and Soudan (2012) conducted a study to determine the extent to which the content of the Palestinian curriculum respects the dimensions of the concept of citizenship and its impact on the social ladder through the analysis of content based on international, regional and local standards. The study pointed out that the curriculum deals with the concept and dimensions of social peace and the role of good citizenship in its construction. But randomly and non-systematic has focused on some indicators and neglected others, and did not achieve horizontal integration between the various subjects adequately, thus affecting the final outputs on the level of individual personality of the student and its impact on society.

Green (2009) stated that since the Ottoman-Turkish conflicts with the Armenians in the early 20th century to the genocide in Bosnia and Rwanda in the last decade, this century saw the end of the wars that had stained the hands of everyone with blood and violence. The study then tackled the emergence of new trends to create reconciliation and social peace, legal, moral and psychological, to promote sectarian, partisan and ethnic acceptance, and to enable former enemies to build a future as neighbors and citizens. At the end of the study, the success of reconciliation and social peace requires a commitment to protect victims, hold perpetrators to account, develop methods of confronting the truth, administer justice and express sympathy.

\section{Commenting on previous studies}

Study on religious field includes studies by Salah (2015) and Assaf (2012). Example of study on the social sciences and in the field of education is the study of Adam (2013); and the field of citizenship as the study of safety and peace or by showing the role of the curriculum in achieving social peace for students includes the studies by Asali and Sweden (2012) and Balmouchi (2014); the impact of internal and external conflicts on achieving social peace is shown by Green (2009).

\section{METHODOLOGY}

In order to achieve the objectives of the study, the researchers used the analytical descriptive approach, which is "the method that studies a phenomenon, event or issue that is currently available, from which information can be obtained that responds to the research questions without the intervention of the researcher" (Abu-Rahma, 2012:77).

There are statistically significant differences at the level of significance $(\alpha \leq 0.05)$ among the average of the sample of the study sample about the role of the Islamic University in the Gaza governorates in achieving social peace among their students due to the variables gender (male/female).

There are statistically significant differences at the level of significance $(\alpha \leq 0.05)$ among the average of the sample of the study sample about the role of the Islamic University in the Gaza governorates in achieving social peace among their students due to the variables college (scientific/humane).

There are statistically significant differences at the level of significance $(\alpha \leq 0.05)$ among the average of the sample of the study sample about the role of the Islamic University in the Gaza governorates in achieving social peace among their students due to the variables level of study ( $2^{\text {nd }}$ and below/ $3^{\text {rd }}$ and above).

\section{Study population}

The population of all the students of the Islamic University in Gaza Governorate, in all colleges, is 15792 male and female students for the academic year 20172018 according to official statistics. The information provided by the official records of students at the Islamic University is shown in Table 1.

\section{Survey sample}

A survey sample of 30 male and female students of the Islamic University from all faculties of the original study was randomly chosen to standardize the study tool and verify its validity through the calculation of honesty and consistency in the appropriate ways to apply to all individuals, the actual sample was calculated within the sample of the study applied to.

\section{Sample of the field study}

A random sample of the original study population was used (400), and $392 \%(98.0 \%)$ was retrieved. This percentage is suitable for conducting various statistical tools and tests on the applied sample of the study. Table 2 shows the distribution of the field sample according to taxonomic variables.

\section{Study tool}

After studying the theoretical frameworks and the previous studies, the researchers constructed a questionnaire consisting of 25 paragraphs, divided into 3 
Table 1. The study population composed of all the students of the Islamic University in all faculties.

\begin{tabular}{lccc}
\hline \multirow{2}{*}{ Educational institution } & \multicolumn{2}{c}{ Students } & \multirow{2}{*}{ Total } \\
\cline { 2 - 3 } & Male & Female & \\
\hline Islamic University & 6253 & 9539 & 15792 \\
\hline * According to official records of the Department of Student Affairs at the \\
Islamic University.
\end{tabular}

Table 2. Distribution of the study sample according to taxonomic variables.

\begin{tabular}{llcc}
\hline Variable & Gender & Number & $\%$ \\
\hline \multirow{2}{*}{ Sex } & Male & 156 & 37.8 \\
& Female & 236 & 62.2 \\
\multirow{2}{*}{ College } & College of Scientific & 206 & 52.5 \\
& Colleges Humanities Colleges & 186 & 47.5 \\
\multirow{2}{*}{ Study level } & Level II and below & 145 & 37 \\
& Level III and above & 247 & 63 \\
\hline
\end{tabular}

main areas: University administration, consisting of 9 paragraphs, faculty members, 8 paragraphs, the curriculum, and consists of 8 paragraphs, and the response to the paragraphs of the questionnaire according to the degree of Likert pentagram (very large, large, medium, few, very few), and correct responses in grades $(5,4,3,2,1)$. All paragraphs were positive, and there were no negative paragraphs.

\section{Validation of the questionnaire}

\section{Apparent honesty of the tool (sincerity of the arbitrators)}

The researchers presented the tool of the study in its initial form on (7) of the arbitrators specialized in the educational administration in the Palestinian universities.

Second, the internal consistency of the questionnaires was validated. The internal consistency of the questionnaires was calculated on the survey sample of 30 students by calculating correlation coefficients between each paragraph and the total score of the field.

Table 3 shows the correlation coefficients between each paragraph of the field and the total score of the field to which it follows, indicating that the correlation coefficients shown are at the significance level (0.05). The significance level for each paragraph is less than 0.05 , honestly, what was put to measure.

\section{Reliability of structural coherence}

Table 4 shows correlation coefficients between the total score of each area of the questionnaire with the total score of the questionnaire paragraphs as a whole, indicating that the correlation coefficients shown are at the significance level (0.05), and thus the areas of the questionnaire are considered to be truthful for what they are designed to measure.

\section{Stability of the paragraphs of the questionnaire}

The stability of the study tool is to ensure that the answer will be almost the same if repeated to the same persons at other times (Assaf, 1995:430). The researchers conducted stability steps on the same exploratory sample in two ways: Alpha Cronbach and the half-division method.

\section{Statistical analysis \\ Cronbach's alpha method}

The researchers used the Cronbach's alpha method to measure the stability of the questionnaire as a first method of measuring stability. Table 5 shows that stability coefficients are high.

It is clear from the previous table that the value of the stability coefficient is between 0.816 and 0.891 and the total stability coefficient is 0.935 . This indicates that the questionnaire has a high degree of stability that researchers are satisfied to apply to the study sample.

\section{Split-half coefficient}

Pearson correlation coefficient was found between the 
Table 3. The coefficient of correlation between each paragraph of the field and the total score of the field to which it belongs.

\begin{tabular}{|c|c|c|c|c|c|c|c|c|}
\hline $\begin{array}{l}\text { Probability } \\
\text { value } \\
\text { (Sig.) }\end{array}$ & $\begin{array}{c}\text { Coefficient } \\
\text { of } \\
\text { correlation }\end{array}$ & $\begin{array}{c}\text { Paragraph } \\
\text { number }\end{array}$ & $\begin{array}{l}\text { Probability } \\
\text { Value } \\
\text { (Sig.) }\end{array}$ & $\begin{array}{c}\text { Coefficient } \\
\text { of } \\
\text { correlation }\end{array}$ & $\begin{array}{l}\text { Paragraph } \\
\text { number }\end{array}$ & $\begin{array}{l}\text { Probability } \\
\text { value } \\
\text { (Sig.) }\end{array}$ & $\begin{array}{c}\text { Coefficient } \\
\text { of } \\
\text { correlation }\end{array}$ & $\begin{array}{c}\text { Paragraph } \\
\text { number }\end{array}$ \\
\hline \multicolumn{3}{|c|}{ University administration } & \multicolumn{3}{|c|}{ Teaching staff members } & \multicolumn{3}{|c|}{ Curriculum } \\
\hline 0.1 & 0.662 & ${ }^{\star} 0.000$ & 0.1 & 0.746 & ${ }^{*} 0.000$ & 1 & 0.599 & ${ }^{*} 0.000$ \\
\hline 2 & 0.634 & ${ }^{*} 0.000$ & 2 & 0.711 & ${ }^{*} 0.000$ & 2 & 0.541 & ${ }^{*} 0.002$ \\
\hline 0.3 & 0.686 & ${ }^{*} 0.000$ & 0.3 & 0.809 & *0.000 & 3 & 0.821 & *0.000 \\
\hline 4 & 0.713 & ${ }^{*} 0.000$ & 4 & 0.658 & *0.000 & 4 & 0.724 & ${ }^{*} 0.000$ \\
\hline 5 & 0.789 & ${ }^{*} 0.000$ & 5 & 0.679 & *0.000 & 0.5 & 0.807 & ${ }^{*} 0.000$ \\
\hline 6 & 0.734 & ${ }^{*} 0.000$ & 6 & 0.721 & *0.000 & 6 & 0.7 & ${ }^{*} 0.000$ \\
\hline 7 & 0.716 & ${ }^{*} 0.000$ & 7 & 0.895 & *0.000 & 0.7 & 0.741 & *0.000 \\
\hline 0.8 & 0.62 & ${ }^{*} 0.000$ & 0.8 & 0.858 & *0.000 & 8 & 0.68 & ${ }^{*} 0.000$ \\
\hline 9 & 0.52 & ${ }^{*} 0.000$ & & & & & & \\
\hline
\end{tabular}

The correlation is statistically significant at $\alpha=0.05$.

Table 4. The correlation coefficient between each area of the questionnaire with the total score of the questionnaire.

\begin{tabular}{clcc}
\hline No. & Field & Coefficient of correlation & Probability Value (Sig.) \\
\hline 1 & University Management & 0.908 & ${ }^{*} 0.000$ \\
2 & Field of teaching staff members & 0.937 & ${ }^{*} 0.000$ \\
3 & Curriculums field & 0.89 & ${ }^{*} 0.000$ \\
\hline
\end{tabular}

The correlation is statistically significant at $\alpha=0.05$.

Table 5. Stability coefficient (Cronbach's Alpha method) for the questionnaire.

\begin{tabular}{clcc}
\hline No. & Field & Number of paragraphs & Cronbach's coefficient \\
\hline 1 & University management & 9 & 0.816 \\
2 & Teaching staff members & 8 & 0.891 \\
3 & Curriculums & 8 & 0.850 \\
\multicolumn{2}{l}{ The total score of the questionnaire } & 25 & 0.935 \\
\hline
\end{tabular}

rate of individual questions of rank and the rate of marital questions for each dimension. Correlation coefficients were corrected using the Spearman-Brown Coefficient correlation coefficient according to the following equation:

Stability coefficient $=\frac{\tilde{\mathrm{N}}}{\tilde{\mathrm{N}}+1} \quad$ where $" \mathrm{~N} "$ correlation coefficient and Table 6 shows the results.

It is clear from the results shown in Table 6 that the Spearman Brown correlation coefficient is high and statistically significant, so that the finalization of the questionnaire is distributable, thus confirming the validity and consistency of the questionnaire, validity of the questionnaire, its validity to analyze the results, answer the study questions, and test its hypotheses.

\section{RESULTS}

The results of the study include a presentation of the results of the study, by answering the study questions and reviewing the most significant results of the questionnaire, which were reached through analyzing their paragraphs, in order to identify the role of the Islamic University in the Gaza governorates in achieving social peace in their students. These included gender, college and level of study.

Statistical analyses of the data collected from the study questionnaire were carried out. The Statistical Package for the Social Sciences (SPSS) was used to obtain the results of the study presented and analyzed in this chapter.

\section{Statistical criterion of the study}

To determine the Statistical Criterion of the study, the length of the cells in the five-dimensional Likert scale was determined by calculating the range between the scales $(5-1=4)$ and then dividing it by the largest value in the 
Table 6. Stability coefficient (half split method) for resolution.

\begin{tabular}{lcccc}
\hline \multirow{2}{*}{ Field } & \multicolumn{3}{c}{ Midterm retail } \\
\cline { 2 - 5 } & $\begin{array}{c}\text { Number of } \\
\text { paragraphs }\end{array}$ & $\begin{array}{c}\text { Coefficient of } \\
\text { correlation }\end{array}$ & $\begin{array}{c}\text { Correlation coefficient } \\
\text { corrected }\end{array}$ & $\begin{array}{c}\text { Probability Value } \\
\text { (Sig.) }\end{array}$ \\
\hline University management & 9 & 0.620 & 0.766 & ${ }^{*} 0.000$ \\
Teaching staff members & 8 & 0.828 & 0.906 & ${ }^{*} 0.000$ \\
Curriculums & 8 & 0.685 & 0.813 & ${ }^{*} 0.000$ \\
The total score of the questionnaire & 40 & 0.836 & 0.911 & ${ }^{*} 0.000$ \\
\hline
\end{tabular}

The correlation is statistically significant at the level of significance $(\alpha=0.05)$.

Table 7. Test in the study.

\begin{tabular}{lll}
\hline Cell length & Relative weight & Degree of approval \\
\hline From 1- 1.80 & From $20-36 \%$ & Very few \\
More than $1.80-2.60$ & More than $36-52 \%$ & Few \\
More than $2.60-3.40$ & More than $52-68 \%$ & Medium \\
More than $3.40-4.20$ & More than $68-84 \%$ & Large \\
More than $4.20-5$ & More than $84-100 \%$ & Very large \\
\hline
\end{tabular}

scale to obtain cell length $(4 / 5=0.80)$, and then this value was added to the lowest value in the scale (the beginning of the scale and the correct one) to determine the upper limit of this cell. Thus, the length of the cells became as shown in Table 7 (Tamimi, 2004:42).

The answer to the first question: What is the role of the Islamic University in the Gaza Strip in achieving social peace from the students' point of view?

To answer this question, one sample T Test was used for one sample to determine whether there were statistically significant differences in the mean of the sample of the sample of the sample of the intermediate class (neutral), which is 3 according to the scale used, relative areas and their order accordingly.

The total score of the questionnaire as a whole obtained a relative weight of $(68.40 \%)$, indicating that the role of the Islamic University in the Gaza governorates in achieving social peace at its request came to a high degree (Table 8). This may be due to the funding problems faced by the higher education institutions in the Gaza governorates in general and the Islamic University in particular, creates a partial absence from strengthening the social peace in their students, in light of the unemployment of the graduates and their lack of assimilation in the local market.

The ranking of the domains according to their relative weights was as follows:

1. The third field: Curriculum: It ranked first with a relative weight of $71.60 \%$, with a high degree of appreciation. This may be due to:

- The interest of the Islamic University in the quality of education provided to the student, and everything that is new in the curriculum books, focusing on activities outside formal courses that encourage the spirit of cooperation and mutual trust between students.

- Enhancing curricula with university requirements that develop positive attitudes among students in the cognitive, behavioral, religious, security, social and political aspects. It is designed for all students without exception.

2. The first field: the university administration: it was ranked second with a relative weight of $68.40 \%$, which is a high degree of appreciation and may be due to:

- The university is the unit responsible for change and modification and development and quality, all done by the administrative body of the university administration.

- University administration in the Islamic University is characterized by knowledge and performance directed towards specific standards and standards that are consistent with international standards, in order to achieve the level of competitiveness in education and the ability to deal with the data of the age and its variables.

3. The second field: the faculty members: it was ranked fourth with a relative weight of $(67.40 \%)$, with a medium rating. This may be due to:

- The conditions experienced by the university professor at the Islamic University of reducing salaries, and 
Table 8. Analysis of the areas of the questionnaire.

\begin{tabular}{lcccccc}
\hline Field & SMA & $\begin{array}{c}\text { Standard } \\
\text { deviation }\end{array}$ & $\begin{array}{c}\text { Relative } \\
\text { weight }\end{array}$ & $\begin{array}{c}\text { Test value } \\
(\mathbf{t})\end{array}$ & $\begin{array}{c}\text { Probability } \\
\text { value (Sig.) }\end{array}$ & Ranking \\
\hline University management & 3.42 & 0.721 & 68.40 & 11.698 & 0.000 & 2 \\
Teaching staff members & 3.37 & 0.782 & 67.40 & 9.397 & 0.000 & 3 \\
Curriculums & 3.58 & 0.762 & 71.60 & 15.246 & 0.000 & 1 \\
The total score of the questionnaire & 3.42 & 0.701 & 68.40 & 10.52 & 0.000 & \\
\hline
\end{tabular}

*The tabular $t$ value at the significance level 0.05 and the freedom level of "391" is 1.96 .

university turmoil because of the economic conditions experienced by the country of siege and wars and division, and others, made some of them unable to give full capacity and productivity, after erosion of their incomes following the volume of the storm witnessed by levels Living and the changes that have been sweeping the country.

\section{Analysis of questionnaire}

\section{Field 1: University Management}

The t-test was used for a single sample, calculation of the arithmetic mean and relative weight, and the order of the paragraphs and results is shown in Table 9.

\section{The results show that the top two items by weight in} this area were:

1. Paragraph 9, which states that "violence and disorder among students shall be rejected as contrary to the rule of law and human rights". $79.60 \%$ indicate that the paragraph has obtained a (large) approval rating from the sample and may be attributed to:

- The Islamic University is working to spread the rule of law, which means ensuring the protection of human rights for individuals and groups equally and equal punishment under the law applied in universities through specialized committees.

- There is no discrimination in one category over another, thus reducing the motives of aggression, the causes of conflict and conflict, while guaranteeing the legitimate rights and interests of all classes of students.

2. Paragraph 7 provides for "a legal system governing relations between students on a clear and transparent basis" $(71.00 \%)$, which indicates that the paragraph has received a high degree of approval from the sample:

- Dissemination of the concept of self-censorship, vision and double vision among students, with the focus of the university on social reform, integrity, responsibility and credibility in all its dealings.

- The university is fairly and resolutely dealing with dissenting behavior, in the most effective and efficient manner, and in a transparent manner, so as to disclose the reasons for its decisions.

\section{The results show that the lowest two items by weight in this area were:}

1. Paragraph 8 states that "the rights and interests of all classes of students shall be guaranteed" (64.20\%), which indicates that the paragraph has obtained a degree of approval (medium) by the sample.

- Ensuring all rights for all students requires great efforts to suit the different nature of the students and to suit all levels and levels.

2. Paragraph 5 states that "students are encouraged to participate in the planning and leadership of social and national initiatives" $(65.40 \%)$, which indicates that the paragraph has obtained a grade of approval (average) by the sample.

- The weak sources of university funding for these initiatives, and the lack of resources and resources that contribute to their implementation, and turn them into existing projects, as the suffocating crises experienced by the universities made them out of interest in the current period.

\section{Second field: faculty members}

The t-test was used for one sample, the calculation of the arithmetic average and the relative weight and the order of the paragraphs and the results are shown in Table 10.

\section{The results show that the top two items by weight in this area were:}

1. Paragraph 1 states that "faculty members shall disseminate the principles and concepts of civil society, build peace and promote a culture of peaceful conflict resolution" (72.20\%), which indicates that the paragraph has received a high degree of approval from the sample.

- The members of the teaching staff take the student with 
Table 9. Arithmetic mean, relative weight, probability value and the order of the field paragraphs.

\begin{tabular}{|c|c|c|c|c|c|}
\hline Paragraph & SMA & $\begin{array}{c}\text { Relative } \\
\text { weight }\end{array}$ & $\begin{array}{c}\text { Test } \\
\text { value }(t)\end{array}$ & $\begin{array}{l}\text { Probability } \\
\text { value (Sig.) }\end{array}$ & Ranking \\
\hline $\begin{array}{l}\text { The university administration applies the law to its students with } \\
\text { complete impartiality regardless of their social status, religious } \\
\text { affiliation or political or party influence. }\end{array}$ & 3.34 & 66.80 & 5.546 & 0.000 & 5 \\
\hline $\begin{array}{l}\text { Provide equal opportunities for students to participate in political, } \\
\text { social and cultural, such as elections, and voluntary efforts within the } \\
\text { walls of the University without prejudice. }\end{array}$ & 3.33 & 66.60 & 5.759 & 0.000 & 6 \\
\hline $\begin{array}{l}\text { Supports students' interactions with the environment, and influences } \\
\text { and influences modernity and cultural renewal. }\end{array}$ & 3.46 & 69.20 & 8.228 & 0.000 & 3 \\
\hline $\begin{array}{l}\text { Workshops and training courses for lecturers are held to train them } \\
\text { on the mechanisms of instilling a culture of tolerance and social } \\
\text { peace. }\end{array}$ & 3.31 & 66.20 & 5.229 & 0.000 & 7 \\
\hline $\begin{array}{l}\text { Encourage students to participate in the planning and leadership of } \\
\text { social and national initiatives. }\end{array}$ & 3.27 & 65.40 & 4.753 & 0.000 & 8 \\
\hline $\begin{array}{l}\text { Encourages the promotion of coordination among universities in } \\
\text { order to consolidate the concepts of social peace. }\end{array}$ & 3.39 & 67.80 & 7.082 & 0.000 & 4 \\
\hline $\begin{array}{l}\text { Establishes a legal system governing relations between students on } \\
\text { a clear and transparent basis. }\end{array}$ & 3.55 & 71.00 & 10.320 & 0.000 & 2 \\
\hline Guarantee the common rights and interests of all classes of students. & 3.21 & 64.20 & 3.581 & 0.000 & 9 \\
\hline $\begin{array}{l}\text { Rejects violence and chaos among students as an antithesis of the } \\
\text { rule of law and human rights. }\end{array}$ & 3.98 & 79.60 & 19.185 & 0.000 & 1 \\
\hline
\end{tabular}

The tabular value at 0.05 and the freedom level of " 391 " is 1.96 .

Table 10. The arithmetic mean, the relative weight, the probability value and the order of the field paragraphs.

\begin{tabular}{|c|c|c|c|c|c|}
\hline Paragraph & SMA & $\begin{array}{c}\text { Relative } \\
\text { weight }\end{array}$ & $\begin{array}{c}\text { Test value } \\
\text { (t) }\end{array}$ & $\begin{array}{l}\text { Probability } \\
\text { Value (Sig.) }\end{array}$ & Ranking \\
\hline $\begin{array}{l}\text { Faculty members disseminate the principles of civil society } \\
\text { and disseminate a culture of peaceful conflict resolution }\end{array}$ & 3.61 & 72.20 & 11.162 & 0.000 & 1 \\
\hline $\begin{array}{l}\text { Provide students with counseling and decision-making } \\
\text { opportunities at the personal and social level. }\end{array}$ & 3.14 & 62.80 & 2.425 & 0.016 & 7 \\
\hline $\begin{array}{l}\text { The rejectionist culture promotes societal norms and } \\
\text { values prevalent in societies }\end{array}$ & 3.28 & 65.60 & 5.083 & 0.000 & 6 \\
\hline $\begin{array}{l}\text { Encourages students to initiate and train in the practice of } \\
\text { integrated scientific thinking for serious problems facing } \\
\text { society. }\end{array}$ & 3.43 & 68.60 & 7.899 & 0.000 & 4 \\
\hline $\begin{array}{l}\text { Students are prepared to uphold the principles of integrity, } \\
\text { transparency, and respect for the rights of others. }\end{array}$ & 3.57 & 71.40 & 11.242 & 0.000 & 2 \\
\hline $\begin{array}{l}\text { Represent the role models and models of ethics to be } \\
\text { followed by their students. }\end{array}$ & 3.52 & 70.40 & 9.086 & 0.000 & 3 \\
\hline
\end{tabular}

The tabular value at 0.05 and the freedom level of "391" is 1.96 . 
great respect and importance, and works to preserve his dignity, so that he has the right to use modern pedagogical methods and appropriate, without objection to any discrimination or differentiated related to sex, religion or any other characteristic.

2. Paragraph 7 states that "students prepare for the principles of integrity and transparency and respect for the rights of others" was ranked second with a relative weight $(71.40 \%)$, which indicates that the paragraph obtained a high degree of approval from the sample. This may be due to:

- The members of the faculty pay great attention to them. All members of the university community work to promote and disseminate good ethical behaviors. They maintain the highest standards of academic, personal and professional integrity in all stages of study, research and work.

\section{The results show that the lowest two items by weight in this area were:}

1. Paragraph 6 states that "the role of oversight shall be reduced and support, model and model shall be strengthened" (62.60\%), which indicates that the paragraph has obtained a grade of approval (medium) by the sample.

- Most members of the faculty of the Islamic University were keen to perform their teaching duties, to prepare them properly, to implement them to the fullest extent, and to adhere to the application of university regulations and laws, so as to be in their behavior and behavior as a role model.

2. Paragraph 2 states that "students shall be provided with opportunities for personal and social counseling and decision-making" (62.80\%), indicating that the paragraph had obtained a grade of approval (medium) by the sample.

- Regulations and regulations may be an impediment to decision-making, as they define policies to be adhered to. This may be due to internal constraints such as financial constraints and technical barriers,

- Decisions may be based on common concepts, influenced by the ideas of others, and lack of a clear objective approach to analyzing the problem to arrive at sound decisions, with the involvement of decision makers.

\section{Field 3: Curriculum}

The t-test was used for a single sample, calculation of the arithmetic mean, relative weight, and order of the paragraphs and results are shown in Table 11.

\section{The results show that the top two items by weight in this area were:}

1. Paragraph 6 provides for "benefiting from the teachings of the Holy Quran, which calls for peace, peace and tolerance" $(81.00 \%)$, indicating that the paragraph has received a (large) approval rating from the sample and may be attributed to:

- Our Palestinian universities pick up their curricula very carefully. These curricula are characterized by the refinement of behavior and the learning of thinking and logic. They also follow the path of Islam, which calls for peace and acceptance of others, and the distance from extremism and deviant ideas that tend to atone for all that do not agree with whims.

- The adoption of religious courses within the requirements of the university taught by students and strengthens the morals of the Koran.

2. Paragraph 8 states that "the principles and values of human rights and the consolidation of democratic principles shall be established by making them a wellestablished culture" (73.00\%), indicating that the paragraph has obtained a large approval rating from the sample and may be attributed to:

- The Palestinian universities are keen to include in the university curricula the courses that consolidate democratic thought, the meanings of freedom, the realization of the mind, free and creative critical thinking, renunciation of violence and self-preservation, and the teaching of human rights and their value over any differences in sex, color, creed or social status.

\section{The results show that the lowest two items by weight in this area were:}

1. Paragraph 1 states: "Curricula shall be characterized by a renewed knowledge of the implications of the role of youth in driving change" $(66.60 \%)$, indicating that the paragraph has obtained a (medium) approval rating from the sample and may be attributed to:

- The lack of development of some curricula, especially the requirements of the university, and the limited methods used to teach the values of justice and peace, and the adoption of new ideas to contribute to the change and development of society.

- Our curricula in our universities need ideas that encourage young people to thinking, creativity, leadership and initiation, and our curricula do not provide 
Table 11. Arithmetic mean, relative weight, probability value, and the order of the field paragraphs.

\begin{tabular}{|c|c|c|c|c|c|}
\hline Paragraph & SMA & $\begin{array}{c}\text { Relative } \\
\text { weight }\end{array}$ & $\begin{array}{c}\text { Test value } \\
(t)\end{array}$ & $\begin{array}{l}\text { Probability } \\
\text { value (Sig.) }\end{array}$ & Ranking \\
\hline $\begin{array}{l}\text { Curricula are characterized by a renewed knowledge of } \\
\text { the implications of the role of youth in driving change. }\end{array}$ & 3.33 & 66.60 & 5.636 & 0.000 & 8 \\
\hline $\begin{array}{l}\text { Develop students' abilities for continuous self-learning in } \\
\text { the pursuit of renewable knowledge. }\end{array}$ & 3.48 & 69.60 & 8.967 & 0.000 & 6 \\
\hline $\begin{array}{l}\text { Invests the past of the Ummah to strengthen social } \\
\text { peace and recognize that strife and intolerance only } \\
\text { produce a social reality. }\end{array}$ & 3.42 & 68.40 & 7.970 & 0.000 & 7 \\
\hline $\begin{array}{l}\text { Alert to the dangers of negative values such as revenge, } \\
\text { retaliation, honor-motivated crime and raise the value of } \\
\text { human dignity in the laws and religions of heaven. }\end{array}$ & 3.58 & 71.60 & 10.504 & 0.000 & 5 \\
\hline $\begin{array}{l}\text { Urges the acceptance of the other and renounce } \\
\text { violence in all its forms. }\end{array}$ & 3.62 & 72.40 & 11.785 & 0.000 & 3 \\
\hline $\begin{array}{l}\text { To benefit from the teachings of the Holy Quran, which } \\
\text { call for peace, peace and tolerance. }\end{array}$ & 4.05 & 81.00 & 19.720 & 19.720 & 1 \\
\hline $\begin{array}{l}\text { Motivate students to modern civic life, which does not } \\
\text { depart from the spirit of Sharia. }\end{array}$ & 3.59 & 71.80 & 10.181 & 10.181 & 4 \\
\hline $\begin{array}{l}\text { To consolidate the principles and values of human rights } \\
\text { and to consolidate democratic principles by making them } \\
\text { a well-established culture }\end{array}$ & 3.65 & 73.00 & 11.964 & 11.964 & 2 \\
\hline
\end{tabular}

The tabular value at 0.05 and the freedom level of " $391 "$ is 1.96 .

opportunities to implement those ideas and aspirations.

2. Paragraph 3 states that "the nation's past shall be invested in strengthening social peace and recognizing that strife and intolerance only produce a social reality" $(68.40 \%)$, which indicates that the paragraph has received a (large) approval rating from the sample and may be attributed to:

- The curriculum is keen to invest the history of the Arab nation, and the conduct of its leaders and leaders. A good example of this is the Prophet's conduct and his influential positions in establishing the first Islamic state on the basis of tolerance and amnesty among Muslims.

\section{Second: Answering the second question}

Are there statistically significant differences at the level of significance between the average estimates of the sample of the study of the role of the Islamic University in the Gaza governorates in achieving the social peace in their students due to the variables of the study (gender, college, level of study)?

To answer this hypothesis, the researchers investigate three hypotheses:
The first hypothesis of the study hypotheses which states:

There were no statistically significant differences at the level of significance between the average estimates of the sample of the study of the role of the Islamic University in the governorates of Gaza in achieving social peace in its students due to gender variable (male, female).

To verify the validity of this hypothesis, the t-test of the independent samples was used to test the differences between the average estimates of the sample members of the study of the role of the Islamic University in Gaza Governorate in achieving the social peace in their students due to the gender variable.

Table 12 shows that the probability value (Sig) for the total score of the questionnaire is 0.998 , which is greater than the significance level $(0.05)$ and the calculated $t$ value is 0.255 , which is less than the tabular $t$ value of 1.96, indicating no differences Statistical significance at the level of significance $(0.05)$ between the averages of the estimates of the members of the study sample of the role of the Islamic University in the governorates of Gaza in achieving social peace in its students attributed to gender variable, as well as in all fields except in relation 
Table 12. Results of the Independent Samples Test $(T)$ between the averages of the sample of the sample of the study of the role of the Islamic University in Gaza Governorate in achieving the social peace in its students due to the gender variable.

\begin{tabular}{|c|c|c|c|c|c|c|c|}
\hline $\begin{array}{l}\text { Statistical } \\
\text { significance }\end{array}$ & $\begin{array}{l}\text { Probability } \\
\text { value (Sig.) }\end{array}$ & $\begin{array}{c}\text { Test value } \\
(\mathrm{t})\end{array}$ & $\begin{array}{l}\text { Standard } \\
\text { deviation }\end{array}$ & SAM & Number & Gender & Fields \\
\hline Statically & 0.042 & 2.527 & $\begin{array}{l}0.698 \\
0.73\end{array}$ & $\begin{array}{l}3.54 \\
3.35\end{array}$ & $\begin{array}{l}156 \\
236\end{array}$ & $\begin{array}{l}\text { Male } \\
\text { Female }\end{array}$ & $\begin{array}{l}\text { University Management } \\
\text { Teaching staff members }\end{array}$ \\
\hline Non-statically & 0.966 & 0.042 & $\begin{array}{c}0.78 \\
0.788\end{array}$ & $\begin{array}{l}3.37 \\
3.36\end{array}$ & $\begin{array}{l}156 \\
236\end{array}$ & $\begin{array}{l}\text { Male } \\
\text { Female }\end{array}$ & $\begin{array}{l}\text { Curriculums } \\
\text { University Management }\end{array}$ \\
\hline Non-statically & 0.084 & 1.73 & $\begin{array}{l}0.815 \\
0.723\end{array}$ & $\begin{array}{l}3.51 \\
3.64\end{array}$ & $\begin{array}{l}156 \\
236\end{array}$ & $\begin{array}{l}\text { Male } \\
\text { Female }\end{array}$ & Teaching staff members \\
\hline $\begin{array}{l}\text { Non-statically } \\
\text { Non-statically }\end{array}$ & 0.998 & 0.255 & $\begin{array}{l}0.764 \\
0.747\end{array}$ & $\begin{array}{l}3.47 \\
3.45\end{array}$ & $\begin{array}{l}156 \\
236\end{array}$ & $\begin{array}{l}\text { Male } \\
\text { Female }\end{array}$ & $\begin{array}{l}\text { The total score of the } \\
\text { questionnaire }\end{array}$ \\
\hline
\end{tabular}

The value of the T-table at the degree of freedom of "390" and the level of significance 0.05 is 1.96 .

to the field of university administration where the potential value is less than the significance level of 0.05 Indicates differences in the assessment of university administration attributed to The variable sex shows through averages as being in favor of males. This may be due to:

- The sex variable did not have any effect on the faculty members and the curriculum in the promotion of social peace because males and females enjoy the same scientific and educational culture, which have the largest role in their views, and are seeking the same social, educational and economic conditions experienced by universities in general, Islamic in particular.

- As for the field of university administration, it is intensifying its directives and publications calling for social peace towards students more than students because students are better able to achieve social peace in their thought and behavior.

The second hypothesis of the study hypotheses which states:

There were no statistically significant differences at the level of significance between the average estimates of the sample of the study of the role of the Islamic University in Gaza Governorate in achieving the social peace in its students due to the variable of the college (scientific, humanitarian).

To verify the validity of this hypothesis, the t-test of the independent samples was used to test the differences between the average estimates of the sample members of the study of the role of the Islamic University in Gaza Governorate in achieving the social peace in its students due to the college variable.

Table 13 shows that the probability value (Sig) for the total score of the questionnaire is equal to 0.134 , which is greater than the significance level (0.05) and the calculated $t$ value is 1.096 , which is less than the tabular value of 1.96. Statistical significance at the level of significance (0.05) between the averages of the estimates of the sample members of the study of the role of the Islamic University in the governorates of Gaza in achieving social peace at the request attributed to the variable college, as well as in all areas. This may be due to:

- The Islamic University applies laws and regulations, follows the same policies, and provides the same services and privileges to all students alike, without discrimination or bias from one faculty to another.

The third hypothesis of the study hypotheses which states:

There were no statistically significant differences at the level of significance between the average estimates of the sample of the study of the role of the Islamic University in Gaza Governorate in achieving the social peace in its students due to the variable level of study (second, lowest, third and higher).

To verify the validity of this hypothesis, the t-test of the independent samples was used to test the differences between the average estimates of the sample members of the study of the role of the Islamic University in Gaza Governorate in achieving the social peace in its students due to the variable of the academic level.

Table 14 shows that the probability value (Sig) for the total score of the questionnaire is 0.025 , which is less than the significance level (0.05) and the calculated $t$ value equals 2.129 , which is greater than the tabular 
Table 13. T test results for the two independent samples (T.Test) to the total variable.

\begin{tabular}{|c|c|c|c|c|c|c|c|}
\hline $\begin{array}{l}\text { Statistical } \\
\text { significance }\end{array}$ & $\begin{array}{l}\text { Probability } \\
\text { Value (Sig.) }\end{array}$ & $\begin{array}{c}\text { Test } \\
\text { value }(t)\end{array}$ & $\begin{array}{l}\text { Standard } \\
\text { deviation }\end{array}$ & SAM & Number & College & Fields \\
\hline \multirow{2}{*}{ Non statistically } & \multirow{2}{*}{0.429} & \multirow{2}{*}{0.792} & 0.717 & 3.4 & 206 & Scientific & University Management \\
\hline & & & 0.729 & 3.46 & 186 & Humanity & Teaching staff members \\
\hline \multirow{2}{*}{ Non statically } & \multirow{2}{*}{0.096} & \multirow{2}{*}{1.669} & 0.794 & 3.31 & 206 & Scientific & Curriculums \\
\hline & & & 0.769 & 3.44 & 186 & Humanity & University Management \\
\hline \multirow{2}{*}{ Non statically } & \multirow{2}{*}{0.051} & \multirow{2}{*}{1.953} & 0.744 & 3.52 & 206 & Scientific & \multirow{2}{*}{ Teaching staff members } \\
\hline & & & 0.778 & 3.67 & 186 & Humanity & \\
\hline \multirow[t]{2}{*}{ Non statically } & \multirow{2}{*}{0.134} & \multirow{2}{*}{1.096} & 0.751 & 3.41 & 206 & Scientific & \multirow{2}{*}{ The total score of the questionnaire } \\
\hline & & & 0.758 & 3.52 & 186 & Humanity & \\
\hline
\end{tabular}

The value of the T-table at the degree of freedom of "390" and the level of significance 0.05 is 1.96 .

Table 14. T test results for the two independent samples (T. Test) to the level variable.

\begin{tabular}{|c|c|c|c|c|c|c|c|}
\hline $\begin{array}{l}\text { Statistical } \\
\text { significance }\end{array}$ & $\begin{array}{l}\text { Probability } \\
\text { value (Sig.) }\end{array}$ & $\begin{array}{c}\text { Test } \\
\text { value }(t)\end{array}$ & $\begin{array}{l}\text { Standard } \\
\text { deviation }\end{array}$ & SAM & Number & Study level & Fields \\
\hline \multirow{2}{*}{ Statically } & \multirow{2}{*}{0} & \multirow{2}{*}{3.668} & 0.616 & 3.6 & 145 & Level II and below & University Management \\
\hline & & & 0.761 & 3.33 & 247 & Level III and above & Teaching staff members \\
\hline \multirow{2}{*}{ Non statically } & \multirow{2}{*}{0} & \multirow{2}{*}{3.613} & 0.681 & 3.56 & 145 & Level II and below & Curriculums \\
\hline & & & 0.821 & 3.26 & 247 & Level III and above & University Management \\
\hline \multirow{2}{*}{ Statically } & \multirow{2}{*}{0.261} & \multirow{2}{*}{1.126} & 0.655 & 3.64 & 145 & Level II and below & \multirow{2}{*}{ Teaching staff members } \\
\hline & & & 0.819 & 3.55 & 247 & Level III and above & \\
\hline \multirow{2}{*}{ Statically } & \multirow{2}{*}{0.025} & \multirow{2}{*}{2.129} & 0.65 & 3.6 & 145 & Level II and below & The total score of the \\
\hline & & & 0.8 & 3.38 & 247 & Level III and above & questionnaire \\
\hline
\end{tabular}

The value of the T-table at the degree of freedom of "390" and the level of significance 0.05 is 1.96 .

value of 1.96, indicating significant differences at the level of significance $(0.05)$ between the averages of the estimates of the members of the study sample of the role of the Islamic University in the governorates of Gaza in achieving the social peace in the student due to the variable level of study, as well as in all fields and showed through the averages of the calculation that it is in favor of the second level and the lowest except for the curriculum. The probability value is greater than the level to denote which demonstrates the absence of differences in the estimation of the area of the school curriculum has been attributed to:

- The Islamic University, which is represented by its university administration, takes care of students at the first level of study. It works to spread awareness, principles and values calling for combating all that is contrary to the laws. It takes care of them, guiding them, and enforcing the university regulations and laws.
Educational system, and treat students on the basis of justice, dignity and respect.

- Follow the Islamic University to the philosophy of building curricula aimed at instilling a culture of coexistence with the requirements and problems of society, and adapt to the daily community life on the principle of respect for each other.

- The Islamic University's recognition of the nature of the tribal and partisan structure of the Palestinian society, which has pushed it to build curricula that promote social peace, renounce violence and tribalism, and consolidate societal stability among all its sectors.

\section{Question 3: What are the proposed ways to improve the role of the Islamic University in the Gaza Strip in achieving social peace in its students?}

The researchers prepared an interview to benefit from the 
views of some educational experts working in Palestinian universities to propose ways to enhance the role of the Islamic University in the Gaza governorates in achieving social peace in their students. In light of the paragraphs of the questionnaire which received less estimates than others, and included 6, and 1 paragraph in the field of curriculum, and 4 paragraphs in the field of faculty members, and the researchers adopted in the classification of paragraphs on the same grades and the middle, the proposals were as follows:

1. Universities apply university regulations and laws to all students regardless of their orientation, gender or affiliation.

2. The necessity of activating the role of conferences, study days, and awareness-raising meetings in order to promote social peace at the student's request.

3. Activating the culture of dialogue through educational institutions and media bodies, and benefiting from the prophet's dialogue as a model for sound dialogue.

4. Working together to establish peaceful concepts that promote the language of dialogue among young people and enhance their role in spreading the concepts of accepting the other away from violence and exclusion, focusing on the culture of tolerance among them.

5. Respect for pluralism in Palestinian society, respect for opinion and opinion, and respect for views.

6 . Enhancing the role of youth in political participation and social initiatives through targeted media programs and campaigns.

7. Promote positive concepts and the spirit of belonging to the homeland away from partisan fanaticism.

8. Enable faculty members to develop themselves socially to contribute to the promotion of social peace in their community.

9. Instruct faculty members to adopt free democratic thought that promotes security and stability in Palestinian society.

10. The need to represent the faculty members as a good example of students in the initiative and volunteerism and social interaction.

11. The Palestinian universities should update Palestinian curricula to include topics that reflect the social reality of Palestinian youth and enable them to deal with it.

\section{RECOMMENDATIONS}

1. Provide the university student with a culture of social responsibility, knowledge of citizenship rights and participation in decision-making.

2. Preparing the university student for continuous selflearning in pursuing the renewed knowledge in the field of human rights, integrity, transparency and fighting corruption.

3. Training students on the principle of initiative and the practice of integrated scientific thinking of serious problems facing society.

4. Enriching the curriculum with renewed knowledge about the implications of social peace and the role of youth in achieving it.

5. Implementing many information activities that contribute to the promotion of social peace.

6. Promote the language of tolerance and dialogue, especially among young people, through joint cultural, artistic and sports activities.

7. That the Ministry of Education and Higher Education adopt programs and activities within schools and universities that promote the concepts and practices of social peace and avoid partisan fanaticism.

\section{RESEARCH FINDINGS}

1. The role of the Islamic University in the governorates of Gaza in achieving social peace at its students came in a medium degree, with a relative weight of $67.40 \%$.

2. There were no statistically significant differences at the level of () between the average estimates of the sample of the study of the role of the Islamic University in the Gaza governorates in achieving social peace in the students due to the variable college, as well as gender except university administration where the differences were in favor of males.

3. There are differences of statistical significance attributed to the variable level of study in favor of the second level and lowest, in all areas except the field of curriculum, and propose a set of ways to strengthen the role of the Islamic University in achieving social peace at the request.

4. Suggest a set of ways to activate the role of Palestinian universities in achieving social peace at their request.

\section{REFERENCES}

Abu-Jidian, I. A., and Taha, R. (2012). The Role of Reform Committees in Implementing Qisas to Establish Social peace in the Oalestinian Society, A field study on the Governorate of North Gaza. Social Peace from an Islamic perspective. Nablus: An-Najah National University.

Abu-Rahma, M. (2012). The pressures of work and its relationship to job satisfaction of educational supervisors in the governorates of Gaza. Master Thesis. Gaza, Palestine: Islamic University of Gaza.

Abu-Salama, M., and Salem, M. (2012). Citizenship and its Relationship to Belonging and Socail Peace Among the students of Al-Quds Open University. The Second Conference of the Faculty of Islamic Law Social Peace from an Islamic Perspective. Nablus: AnNajah National University

Adam, A. (2013). The role of education in the development and promotion of social peace. Sudan: Bahri University.

Albdeiwi, K. (2011). Dialogue and Social Peace Building, 1, King Abdulaziz Center for National Dialogue, Riyadh.

Alsafar, H. (2002). Social security: its components and protection. 1: Dar Al-Saki for printing and publishing.

Amer, N. (2013). Factors of civil peace and civil strife in Syria Damascus: Center for civil society and democracy. 
Assaf, M. (2012). Mediation in religious discourse and its impacts on social peace. Conference of the Faculty of Islamic Lawll - Social peace from an Islamic perspective. Nablus: An-Najah National University.

Awad, Y. (2014). The role of social responsibility in strengthening civil peace practices for university youth. The Fourth International Conference - Education on International Humanitarian Law (p. 2014). Algeria: Center for the Generation of Scientific Research.

Badawi, K. (2011). Dialogue and social peace building. Riyadh: King Abdulaziz center for national dialogue.

Balmoshi, A. R. (2014). The role of educational curricula in achieving a culture of social peace. Paper presented to the Fourth International Conference, Education on International Humanitarian Law, Center for the Generation of Scientific Research, Algeria: Al-wady University.

Gebkub, M. (2017). The Problem of Social Peace in the Shadow of Economic Crisis in the Arab World, Case Study of Algeria (20062016) (unpublished Master Thesis). University of Xian Ashour Djelfa, Algeria.

Green, P. (2009). Reconciliation and forgiveness in divided societies: A path of courage, compassion and commitment.

Hudhud, I. (2017). Islamic Education and Social Peace Building. Paper presented to the Fourth World Conference on Islamic Studies. Thailand: College of Islamic Studies.

Hussaini, M. (2000). Crown of the bride jewels dictionary. Beirut: Dar Al-Fikr.

Kilani, S., and Tafha, L. (2012). The impact of respect for citizenship rights in the social ladder. Conference of the faculty of Islamic Law II Social peace from an Islamic Perspective. Nablus: An-Najah University.

Majidi, A. M. (2014). In the Islamic perception of social peace. Retrieved from www.hespress.com.

Muslim, M. (1996). The correct and correct reference to the transfer of justice from justice to the Messenger of God $\square$ famous: Saheeh Muslim. Investigation: Mohamed Fouad Abdel Baqi. I. Beirut: House of Revival of Arab Heritage.

Omar, A. E.H. (2016). Pillars of social peace in the muslim family. Policy and law books, pp. 233-258.
Salah, A. (2015). The role of intellectual security in achieving social peace. Journal of the Faculty of Law for Legal and Political Sciences, pp. 494-550.

Saleh, Q. (2002). The problematic Relationship between power and the individual in the Arab society. The Arab Conference, the role of psychology in facing the challenges of the present and the Arab future. Baghdad.

Tamimi, F. (2004). The Effectiveness of Using Quality Management System (ISO 9001), Development of Management of Administrative Units in the Ministry of Education in Jordan from the Point of View of Its Employees (unpublished PhD thesis), Amman Arab University, Jordan.

Citation: Sheldan, F. K., and Qwaider, M. N. (2018). The role of Palestinian universities in the Gaza governorates in achieving the social peace for its students and ways to strengthen it: Islamic University as a case study. African Educational Research Journal, 6(4): 317-333. 